\title{
A Review of the Methane Hydrate Program in Japan
}

\author{
Ai Oyama * (1) and Stephen M. Masutani
}

Hawaii Natural Energy Institute, University of Hawaii, Honolulu, HI 96822, USA; stephenm@hawaii.edu

* Correspondence: aioyama@hawaii.edu; Tel.: +1-808-956-5711

Received: 2 August 2017; Accepted: 16 September 2017; Published: 21 September 2017

\begin{abstract}
In this paper, methane hydrate R\&D in Japan was examined in the context of Japan's evolving energy policies. Methane hydrates have been studied extensively in Japanese national R\&D programs since 1993, with the goal of utilizing them as an energy resource. Currently, the Research Consortium for Methane Hydrate Resources in Japan (MH 21) is in the third phase of a project that began in early 2002. Based on publicly available reports and other publications, and presentations made at the ten International Workshops for Methane Hydrate Research and Development, we have attempted to provide a timeline and a succinct summary of the major technical accomplishments of MH 21 during project Phases 1, 2, and 3.
\end{abstract}

Keywords: methane hydrate; MH 21 Research Consortium; Japan; energy policy

\section{Introduction}

Gas hydrates have attracted attention as a potential unconventional natural gas resource, and numerous research and development (R\&D) projects have been undertaken worldwide [1-3]. Two key components of the International Workshop on Methane Hydrate Research and Development (the Fiery Ice Workshop), which began in 2001, are to report gas hydrate research trends in different countries and to facilitate information exchanges on hydrates between researchers and stakeholders [4].

The Government of Japan established the first and largest national R\&D program on methane hydrate in 1993 and has continued to promote research projects in this area since that time. The Research Consortium for Methane Hydrate Resources in Japan (MH 21 Research Consortium) has been coordinating the development of offshore gas hydrates as a natural gas resource for 15 years, and its progress and achievements have been reported in the National Activity sessions and the National Report sessions during past Fiery Ice Workshops [5-11].

Given the global significance of the Japanese national methane hydrate R\&D program, this paper attempts to provide a concise review of the program's accomplishments in the context of Japan's overall energy strategy. Impacts of the 2011 Great East Japan Earthquake disaster on the MH 21 Research Consortium and the current energy situation in Japan, also are discussed. Publicly available information written in Japanese comprised the primary resource for this review, as well as presentations from the Fiery Ice Workshops. The paper is organized chronologically, in the order of occurrence of relevant events.

\section{Energy Supply in Japan}

According to the Annual Report on Energy for fiscal year (FY) 2016, 91.1\% of the total primary energy consumed in Japan comes from fossil fuel sources [12]. Since it has limited indigenous resources, Japan imports over $80 \%$ of its energy; hence, it is a critical priority of the Government to ensure stability of its energy supply train, to diversify energy sources, and to develop advanced technologies to exploit possible domestic energy resources. In this context, natural gas has received serious consideration as a relatively clean energy resource, and its use has been actively promoted; however, competition for 
natural gas has increased recently [13]. In this section, Japanese energy policies since the 1960s are briefly reviewed to provide some background regarding how the MH 21 Research Consortium came to be organized.

\subsection{Changes in Energy Policies in Japan}

Before the period of high economic growth that began in the 1960s, domestic coal was a major source of energy in Japan. During the 1960s and early 1970s, Japan's energy supply shifted from coal to oil imported from the Middle East, and consumption increased significantly. In 1970, $75.5 \%$ of the primary energy supply was imported oil; therefore, the first oil crisis in 1973 severely affected Japan, compelling them to diversify their sources of energy to include coal, natural gas, and nuclear energy. The second oil shock in 1979 accelerated the introduction of energy sources other than oil and promoted the further development of technologies to utilize renewable resources such as solar and geothermal [12].

The extreme vulnerability to the oil crises forced Japanese policy makers to confront the problem of ensuring a stable energy supply. In the 1970s and 1980s, several countermeasures were implemented. As one of these remedies, two long-term, large scale energy R\&D projects were initiated with goals of promoting and commercializing new energy technologies and energy conservation. The Sunshine project, launched in 1974, was Japan's first national technological program and it was carried out by the Agency of Industrial Science and Technology (currently the National Institute of Advanced Industrial Science and Technology, or AIST) of the Ministry of International Trade and Industry, or MITI (currently the Ministry of Economy, Trade and Industry, or METI). The objectives of the Sunshine project were to develop solar, geothermal, wind, coal, and hydrogen energy technologies in order to reduce Japan's dependence on oil [14,15]. AIST also started the Moonlight project in 1974 to pursue innovative energy conservation technologies, such as improvements in energy conversion efficiency [15,16].

Starting in the 1990s, regulatory and institutional reforms were implemented to strongly integrate economic competitiveness and environmental considerations into energy policies. The action program for the prevention of global warming was approved by the Japanese Cabinet in 1990, and the Sunshine and Moonlight projects were consolidated under the New Sunshine project that began in 1993. The primary goals of the New Sunshine project were, once again, the development of new energy and energy conservation technologies. In addition, an action program that focused on mitigating climate change through innovative technology development was prioritized under this new project $[15,17]$.

The development of clean energy technology accelerated after the international Kyoto Protocol was accepted at the third session of the Conference of the Parties (COP 3) in 1997. In 2002, the Basic Act on Energy Policy was enacted in Japan. Accordingly, the Basic Energy Plan was approved by the Cabinet in 2003, establishing energy security, improving economic efficiency, and environmental suitability as the pillars of Japan's energy policy. In addition to the national projects mentioned above, other efforts were made by the government to encourage changes in society that would serve to fulfil these three basic principles.

Although energy security remained vulnerable, since Japan would continue to need to import fossil fuel, reducing the country's dependency on oil was expected to provide significant benefits. Toward this end, natural gas emerged as a viable alternative to oil.

\section{2. $M H 21$}

In the late 1970s, offshore seismic data revealed the existence of bottom-simulating reflectors (BSR) in several regions within Japan's Exclusive Economic Zone (EEZ). A BSR is a line that appears in marine seismic data, which occurs below, and generally parallel to, the seafloor, crossing sediment layers. BSRs indicate a sudden change in seismic impedance, such as when gas-rich sediments exist immediately beneath methane hydrate deposits due to the geothermal temperature gradient. BSRs therefore have been utilized as one indicator of the possible existence and depth of a hydrate reservoir $[2,18,19]$. 
Bottom-simulating reflectors in the Nankai Trough in the Pacific Ocean east of Japan and in other offshore areas began to be reported after 1982 ([20] p. 5, [21] p. 774, [22] p. 266). As evidence of significant methane hydrate reservoirs continued to mount, investigations were conducted to assess the feasibility of producing methane fuel from this potential indigenous energy resource [21] (p. 776). In 1991, a committee to carry out a research survey of unconventional natural gas was established by the Institute of Applied Energy and other organizations under the lead of MITI. Since 1993, the sole focus of this survey became natural gas hydrate [21,23]. Hereinafter, natural gas hydrate will be referred to as methane hydrate, since the main component of natural gas typically is methane.

In 1994, a report was submitted to the petroleum council which advocated fundamental research on, and technological development for, methane hydrate to explore the possibilities for future commercialization. In response, a committee to promote and to oversee methane hydrate R\&D was organized by JNOC (Japan National Oil Corporation; currently Japan Oil, Gas and Metals National Corporation, JOGMEC). In 1995, JNOC initiated the Special Research: Methane Hydrate Research and Development Program in cooperation with 10 private companies, with a long-term vision of producing methane gas from an offshore well that tapped a methane hydrate reservoir [22]. The following year, Satoh et al. [24] published an article which estimated that methane hydrate in-place resources around Japan contained $4.65 \times 10^{12} \mathrm{~m}^{3}$ of gas, which was approximately two orders of magnitude greater than the country's natural gas consumption in $1994\left(\sim 5.4 \times 10^{10} \mathrm{~m}^{3}\right)[21,23,25-27]$. These developments served to inspire methane hydrate research efforts both within and outside Japan.

Following the 1998 successful joint drilling project in the Mackenzie Delta conducted by Japan, Canada, and the USA; the discovery of high-saturation methane hydrates in sand reservoirs during the offshore MITI well project in 2000, and the development of novel sampling and analytical tools, such as the Pressure-Temperature Core Sampler (PTCS) to recover hydrate cores while maintaining in situ pressure and temperature [22], a report was submitted to the Japanese Government that proposed an increase in the proportion of natural gas in the primary energy supply. That report also suggested that the government assume the lead role in methane hydrate R\&D, and provide support for basic geophysical exploration and methane hydrate well drilling in the medium- to long-term. In response, METI organized the Methane Hydrate Development Review Committee. After consideration of input from stakeholders and the results of the two-dimensional seismic survey performed in the eastern Nankai Trough in 2000, the Review Committee announced Japan's Methane Hydrate R\&D Program in 2001. The MH (abbreviation for methane hydrate) 21 Research Consortium (MH 21) was established in March 2002 [25,28,29].

Due to an almost complete absence of indigenous conventional fossil fuel resources, energy security has been the driving factor behind government support of methane hydrate research in Japan. The MH 21 Research Consortium emerged as a response to this critical priority and its organization reflects the strategy developed as a result of prior projects and programs, and input from stakeholders. Expectations for the Consortium can be found in the Kyoto Protocol Target Achievement plan, the Basic Energy Plan, and the Basic Plan on Ocean Policy, which were approved by the Cabinet in 2005, 2003, and 2008, respectively [13,30].

\section{MH 21 Progress and Achievements}

This section describes the MH 21 Research Consortium's accomplishments. The mandate of the Consortium is to develop methane hydrate as a future energy resource and pursue technological developments in the areas of drilling and production that are needed to economically utilize methane hydrate and, consequently, contribute to the stability of Japan's energy supply [13]. The stated official goals of the project are [31] (p. 6):

"In order to improve technologies for the commercial production of methane hydrate distributed offshore Japan, the following goals have been configured. To help turn the plan into reality, efficient technological developments will be promoted in conjunction with 
ideas from international collaborations. This scheme and associated achievements will be reflected in government energy policy.

1. Clarification of methane hydrate occurrences and characteristics offshore Japan;

2. Assessment of methane gas amounts trapped in promising methane hydrate bearing offshore areas;

3. Selection of methane hydrate resource fields from promising methane hydrate bearing offshore areas and deliberation of economic potential;

4. Implementation of production test in the selected methane hydrate resource fields (until FY 2011);

5. Improvement of technologies for the commercial production (until FY2016);

6. Establishment of a development system complying with environment."

This plan was implemented in three phases. Phase 1 initially was scheduled to run for six years, Phase 2 for five years, and Phase 3 also for five years. Specific plans for each phase would be amended as needed, based on regular progress assessments. Detailed and technical information on Phase 1 achievements are available in the English version of the MH 21 Research Consortium webpage [13], in "Phase 1 Comprehensive Report of Research Results (August 2008 Edition)" [31], as well as in a number of published journal papers [32-36]. A succinct summary of the three phases is provided below.

By the time that Phase 1 began in FY 2001, the existence of significant methane hydrate deposits in sandy sediments had been confirmed. The primary goals of Phase 1 were to secure detailed data on the distribution and fundamental properties of methane hydrate in the ocean around Japan; assess the volume of methane gas in the Nankai Trough area; test and validate a practicable methane gas production technology from methane hydrate bearing sediments; and, perform environmental impact assessments [13,27]. Major events that occurred during Phase 1 included [27,31]:

- 2001-2002: $470 \mathrm{~m}^{3}$ of gas was successfully produced for five days using a hot water circulation (thermal) method in the first onshore methane hydrate production test. The test was carried out in the Mackenzie Delta, Canada via a collaborative research agreement between Japan, Canada, Germany, USA, and India. Hydrate depressurization also was tested.

- FY 2001-FY 2002: Two-dimensional and three-dimensional seismic surveys in the eastern Nankai Trough were conducted by METI.

- 2004: METI exploratory test wells "Tokai-oki to Kumano-nada" were drilled.

- 2005: An interim project review was conducted and Phase 1 was extended for two years.

- 2006-2007: The second onshore methane hydrate production test (the first winter) was carried out in Canada with a goal of testing the depressurization method at a field scale and refining a gas production simulator code. $830 \mathrm{~m}^{3}$ of gas was produced over approximately $12.5 \mathrm{~h}$ of depressurization; however, the production test was interrupted by a significant amount of sand that flowed into the well earlier than expected, causing malfunction of the pump. Completion of this test was consequently postponed until 2008 [31] (p. 26).

- 2007: On 5 March 2007, METI announced that the estimated volume of methane hydrate in-place gas resources in the eastern Nankai Trough was approximately 40 Tcf (about 1.1 trillion $\mathrm{m}^{3}$ ) [37].

- 2008: The second onshore methane hydrate production test (the second winter) was completed in Canada. About $1.3 \times 10^{4} \mathrm{~m}^{3}$ of gas was produced continuously for six days employing the depressurization method. To prevent produced sand flow into the well, a sand screen was employed [31] (p. 26).

- 2008: Final evaluation of Phase 1 was conducted.

Highlights of the Phase 1 accomplishments are reported as follows [22,27,31]: 
1. METI exploratory test wells "Tokai-oki to Kumano-nada" drilled in 2004 revealed that the high-saturation methane hydrate in sand reservoirs found in 2000 comprised alternating turbidite sand and mud layers. These zones of concentrated methane hydrate in the eastern Nankai Trough area were considered to have a high potential for development [22,31].

2. A method to identify concentrated methane hydrate zones based on the seismic data was established.

3. The amount of in-place methane hydrate gas in the eastern Nankai Trough was calculated by using a probabilistic approach.

4. The PTCS device developed earlier was improved and recorded an $80 \%$ core recovery success rate, maintaining sample in situ pressure $90 \%$ of the time during "Tokai-oki to Kumano-nada" test well drilling in 2004 [31] (p. 47). Other laboratory equipment and research techniques to measure methane hydrate properties and decomposition behavior at in situ conditions were also developed; e.g., the Microfocus X-ray CT instrument and techniques to determine porosity and hydrate saturation fraction of cores by imaging. The complete list of laboratory facilities for core testing is provided on page 60 and page 61 in "Phase 1 Comprehensive Report of Research Results (August 2008 Edition)" [31].

5. Japan's own well production simulator, MH21-HYDRES, was created to predict the behavior of methane hydrate-bearing layers.

6. The depressurization method was confirmed to be a valid gas production technique through the two onshore production tests conducted in Canada.

In FY 2007, METI announced that, based on data from their offshore surveys, and the analysis of these data and model results, the volume of methane hydrate in-place resources in the eastern Nankai Trough area was approximately 1.1 trillion $\mathrm{m}^{3}$. This amount is equivalent to about a 10 year supply of Japan's annual natural gas consumption in FY 2012 [38].

Phase 2 began in 2008, after the two-year extension of Phase 1. The objectives of Phase 2 were to identify the technological problems through offshore methane hydrate production tests; to confirm an economically feasible gas production method; to evaluate methane hydrate distributions off the coast of Japan; and, to devise appropriate environmental impact assessment methods. Since gas production times during the second onshore production tests in 2007 and 2008 were relatively short, the Phase 2 objectives also included plans for a longer-term onshore production test [30]. Major events that took place during Phase 2 were [13,30]:

- FY 2009-FY 2011: Preparations for the offshore production tests were undertaken. Phase 2 was extended by two years until FY 2015.

- FY 2011: An interim project review was conducted.

- FY 2012-FY 2015: The first offshore production test was conducted. On 19 March 2013, JOGMEC made a preliminary announcement reporting that approximately $120,000 \mathrm{~m}^{3}$ of gas was produced from a methane hydrate layer under the seabed utilizing the depressurization method; production continued for about six days [39]. It subsequently was officially disclosed that "a cumulative $119,500 \mathrm{~m}^{3}$ of gas at atmospheric conditions were produced" [40] (p. 301) and detailed technical reports on this offshore production test were prepared and made available in English [40-42]. On 6 November 2014, JOGMEC and the National Energy Technology Laboratory of the USA Department of Energy signed a Memorandum of Understanding for a joint long-term onshore production test in Alaska, USA [43].

- FY 2015: A final evaluation of Phase 2 was conducted.

Although a comprehensive report on the research results of Phase 2 has not yet been released, highlights of Phase 2 achievements are stated on page 11 of "Phase 2 Technical Evaluation Report" as follows [44]:

- "The first offshore MH production test took place off the coast of Japan. 
- Assessments of MH resource field properties were completed.

- A conceptual subsea gas production system was evaluated.

- Continued development and refinement of gas production technology.

- Development of production behavior assessment technology.

- Methods were identified to evaluate geological layer properties.

- Exploration of MH reservoirs off the coast of Japan continued.

- Possible environmental risk analysis and counter measures were considered.

- Development of environmental assessment technologies.

- Environmental impact assessments were conducted based on the offshore production test.

- An assessment of economic feasibility was performed."

Major achievements of Phase 2 mentioned in the Action Plan for Phase 3 [30] were the field verification of the ability of the depressurization method to continuously produce gas from methane hydrate-bearing seafloor sediments; the collection of extensive data from the gas production well and monitoring wells; and, the analysis of these data to explain methane hydrate decomposition behavior near the wells.

Phase 3 was shortened by two years. Since Phase 2 was extended for two years through FY 2015, Phase 3 currently is scheduled to run for 3 years, from FY 2016 through FY 2018. The focus of the Phase 3 is to establish a technical platform for commercialization. Specifically, there are three objectives: (1) to accumulate sufficient knowledge and data to determine whether it is possible to establish a technological base that can produce gas for the long-term; (2) to improve the reservoir simulator to a level where it can accurately predict the long-term gas production behavior; and, (3) to propose a strategy for a viable production system and evaluate economic performance and assess environmental impacts.

In a presentation made in December 2016, Yamamoto [45] discussed key remaining barriers to commercialization of methane hydrate energy which have been identified by MH 21 and are reflected in the aforementioned Phase 3 objectives. These challenges include:

- understanding long-term methane hydrate reservoir and gas production behaviors and developing the ability to estimate the amount of produced gas;

- confirmation of production methods and technologies that yield a high energy profit ratio and ensure well integrity; specific areas of interest are:

- determining the viability of alternative production methods such as a well stimulation or enhanced recovery;

- preventing produced sand flow into a production well and seawater and groundwater flow into a reservoir;

- preventing release of produced gas;

- clarification of possible environmental impacts including:

- effects of typhoons and other meteorological phenomena, and the Kuroshio current, on marine hydrate gas production systems;

- how geological events might affect the safety of personnel and marine hydrate gas production systems (gas production from methane hydrate in the Nankai Trough is believed to be unlikely to induce a large-scale seafloor slide or earthquake).

Recently, the second offshore methane hydrate production test was carried out near the Atsumi/Shima peninsula during the period between April and June 2017. On 29 June 2017, METI announced the completion of this test, reporting preliminary values of produced gas of approximately $35,000 \mathrm{~m}^{3}$ for the first production well over 12 days and $200,000 \mathrm{~m}^{3}$ for the second production well over 24 days [46]. A long-term onshore methane hydrate production test on the North Slope of Alaska 
is planned after FY 2017. Data from this test on extended gas production behavior and the associated problems will be applied to the development of the gas production system for marine methane hydrates [30] (pp. 5,6). Associated projects led by private companies are expected to commence around FY 2023 to FY 2028; this will depend on the international energy market and other factors at that time [30].

Methane hydrate exploration and the development of production technologies have advanced significantly in Phases 1 and 2, to the extent that commercial gas production from methane hydrate now appears feasible. The different Phases of the project, however, did not proceed as originally planned. Both Phases 1 and 2 were extended for two years, and Phase 3 was shortened by two years, making the 16-year-project an 18-year-project. This ability to accommodate changes based on regular progress evaluations was probably a primary reason for the continuation and success of this long-term national project. The Basic Plan on Ocean Policy, which identifies methane hydrate as a future domestic energy resource and advocates methane hydrate R\&D projects, was also revised in 2013 " . . in response to the Great East Japan Earthquake and mounting expectations for the development of marine energy and mineral resources" [47] (p. 1). In the next section, the wrenching changes in the energy landscape in Japan that occurred as a consequence the Great East Japan Earthquake and its impacts on the MH 21 Research Consortium will be discussed.

\section{The Great East Japan Earthquake and MH 21}

At 2:46 p.m. JST on 11 March 2011, in the middle of Phase 2 of MH 21, the Great East Japan Earthquake struck and generated a powerful tsunami that reached heights of up to $40 \mathrm{~m}$ at some points along the coastline. The magnitude 9.1 earthquake and subsequent tsunami would end up radically altering Japan's energy policy and serve as a catalyst for the expansion and diversification of its liquefied natural gas (LNG) supply train, and significantly raise expectations for the development of unconventional natural gas resources.

From the perspective of national energy policy, the landmark event caused by the earthquake and tsunami was the meltdown and radiation releases that occurred at the Fukushima Daiichi Nuclear Power Plant. In response to strong public backlash, all of the nuclear power plants in Japan stopped operating in May 2012. The Kansai Electric Ohi Power Stations 3 and 4 subsequently restarted in July 2012, but operated only for 1 year and 2 months before being shut down again in September 2013, leaving Japan to overwinter without any nuclear power generation [12].

In November 2009, a public opinion poll of 3000 people 20 years of age or older, conducted by the Cabinet Office of the Japanese government, indicated that $59.6 \%$ of Japanese adults supported expansion of nuclear power generation, $18.8 \%$ favored maintaining the status quo, and $16.2 \%$ opposed nuclear power plants (5.4\% of persons polled had no response) [48]. The small percentage of people wanting to decrease or abolish nuclear plants grew significantly in the wake of the Fukushima disaster, reaching $41 \%$ in two different opinion polls conducted by the Asahi and Yomiuri newspapers in April 2011 [49], and increasing to 71\% in December 2011 (NHK Broadcasting Culture Research Institute opinion poll [50]), and 77\% in December 2013 [51].

Prior to the Great East Japan Earthquake, in excess of $30 \%$ of electricity in Japan was provided by its nuclear power stations. Nuclear power also was a key component in the country's strategy to reduce its greenhouse gas emissions. As a consequence of the Fukushima accident, Japan lost one of the main pillars of its stable energy supply infrastructure and was forced to scramble for replacements. In FY 2011, Japan's international balance of trade fell into deficit for the first time in 31 years, since the second oil crisis in 1979. In FY 2012, the annual cost of additional fuel imports for thermal power generation increased by approximately 3 trillion yen (US $\$ 38$ billion, based on average 2012 exchange rates) due to the suspension of nuclear power plant operations, and energy transactions accounted for $34 \%$ of all trades during the year [52,53]. Taken in combination with the sharp $25 \%$ depreciation in the value of the yen that occurred in 2013 , reducing the instability and vulnerability of its energy 
supply by cutting fuel procurement costs and diversifying fuel suppliers became an urgent issue for the Japanese economy [52] (pp. 12,13).

Consumer dissatisfaction over increasing electricity prices due to the rising costs of fuel imports appeared to temper opposition to nuclear power. In a poll conducted by Jiji Press in April 2012, 57\% opposed nuclear power plant operation, but $70 \%$ were also unhappy with the associated jump in the price of electricity. Although the majority of the public did not want nuclear power plants to start up again, a larger percentage also were frustrated with increasing electricity prices [54].

In the period following the earthquake, LNG emerged as the most promising candidate that might ensure the stable and inexpensive procurement of imported energy, while minimizing harmful emissions to the environment [55]. Correspondingly, in September 2012, the world's first LNG Producer-Consumer Conference was held in Tokyo, and during the Conference, the Japanese Government took the position that the existing LNG pricing method linked to crude oil prices was no longer rational, and that an alternative pricing method was necessary [56] (p. 59). Since natural gas' share of the total primary energy sources for Japan had expanded from 19.2\% in FY 2010 to $24.5 \%$ in FY 2012, the soaring costs of importing LNG contributed to a record trade deficit of about 13.75 trillion yen (about US \$137 billion, based on average 2013 exchange rates) in FY 2013 [56]. In response, Japan implemented various countermeasures. Efforts were made to diversify its suppliers of LNG and to suppress the import price of LNG. One of the primary targets of this supply diversification was shale gas, which had been flourishing in the USA and (to a lesser extent) Canada.

In the USA, technological innovations made it possible to produce natural gas from deep shale (mudstone) layers [57]. Since an extensive natural gas distribution infrastructure was already in place in the USA, commercial production of unconventional shale gas expanded quickly, to the extent that shale gas has come to be accepted as a conventional energy resource. Shale gas production increased in the 2010s, and in 2014, the known remaining shale gas recoverable inventory was estimated to total about $750 \mathrm{Tcf}\left(21\right.$ trillion $\left.\mathrm{m}^{3}\right)$ [58]. As a result of this increased supply, natural gas prices have been sluggish in the USA since 2008 [56,59]. Japan, which is pursuing rapid diversification of its LNG suppliers, acquired an export approval from the USA on February 2014 for all four of the proposed LNG projects involving Japanese companies. Liquefied shale gas (LSG) from the USA arrived in Japan for the first time in January 2017. Ultimately, Japan is expected to import about 17 million tonnes of LSG annually from the USA, which is equivalent to about $20 \%$ of its total LNG imports. In addition, several LSG projects located in Canada involving Japanese companies are currently being considered [56].

While the diversification of LNG suppliers was being undertaken as a response to changes in the energy situation in Japan after the earthquake, expectations also increased regarding the development of domestic energy resources, including unconventional natural gas. Although the importance of methane hydrate development was already established in the Marine Basic Plan, formulated in March 2008 and based on the Ocean Basic Law (established in 2007), the growing expectations for future domestic energy resource development and the increasing demand for high-priced natural gas was noted in the 2013 revision of the Marine Basic Plan. From a long-term perspective, it is an imperative for Japan to establish a framework of environmentally-friendly, secure energy sources. With respect to this overarching goal, methane hydrate development is well-positioned as an important future investment [60].

As a result of the disruptions in energy supply caused by the Great East Japan Earthquake and tsunami, and the associated shifts in policy and public perceptions, it became necessary for MH 21 to provide clear information about the economic efficiency of the methane hydrate resource development, in the context of price competitiveness. The economic efficiency of fuel gas production from methane hydrate and commercialization was considered to be a prerequisite for the project from the start of MH 21; however, accurate assessments of economic efficiency and viability were not really possible until appropriate production technologies and methods had been identified. When discussing the economics of gas production from methane hydrate, the following factors are believed to be important: 
"The biggest extrinsic factors are oil fields, gas prices, and foreign currency exchange. Especially the cost insurance and freight (CIF) price of imported LNG is important. The primary thing to be demanded is the selling price of gas from methane hydrate to be cheaper than or be competitive against the CIF price of imported LNG" [28] (pp. 190, 191).

The technical accomplishments to date of MH 21 have provided important information for ongoing economic analyses. Advancements in exploration methods made during Phases 1 and 2, and extensive field surveys have yielded data that have been used to refine the estimated amount of in-place methane hydrate resources in the eastern Nankai Trough. The production tests have identified viable technologies and methods to recover gas from offshore methane hydrate deposits, which, in turn, mean that it has become possible to obtain more realistic predictions of the cost of gas production as well as any environmental penalties. The tests have also identified areas where conventional natural gas production techniques need to be modified in order to be applied successfully in methane hydrate reservoirs (e.g., the depressurization approach employed for methane hydrate deposits in sandy sediments) [28]. In consideration of the progress and accomplishments of the MH 21 program and its importance to the evolving energy strategy for Japan, MH 21 is pursuing Phase 3 with a specific goal of establishing a technical platform for commercialization.

\section{Summary}

In this paper, methane hydrate R\&D in Japan has been examined in the context of Japan's evolving energy policies. As a consequence of Japan's lack of domestic energy resources and its dependence on imported fuel, energy security, along with the balance of trade issues, have been overriding concerns for decades. Discovery in the late 1970s of possibly significant natural gas reservoirs stored in offshore methane hydrate deposits within Japan's EEZ sparked interest in this unconventional energy resource, initiating a number of exploratory investigations. As the prospect of a new domestic methane hydrate energy resource began to gain traction, the Japanese Government began its support of methane hydrate R\&D which has continued to the present and is centralized under the Methane Hydrate Research Consortium, MH 21.

The earlier energy paradigm, wherein nuclear power was expected to play an increasing role in addressing the aforementioned energy security and balance of trade concerns, while reducing carbon emissions, was shattered by the Fukushima Daiichi Nuclear Power Plant accident caused by the Great East Japan Earthquake in 2011. All of the nuclear power generation plants were subsequently shut down for various periods of time, resulting in a surge in fossil fuel imports that led to the first trade deficits in decades. At the time, LNG was identified as a leading candidate that could improve energy security and reduce, to an extent, the environmental impacts of increased combustion of fossil fuels. Along with the diversification of LNG suppliers, sources of unconventional natural gas, including methane hydrates, received increasing attention as possible countermeasures to energy supply uncertainties. In this atmosphere, MH 21 is proceeding with Phase 3 of the program that began in early 2002, with the goal of establishing a technical platform for the commercialization of gas from methane hydrate.

Based on publicly available reports and other publications, and presentations made at the Fiery Ice Workshops, we have attempted to provide a timeline and succinct summary of the major technical accomplishments of MH 21 during Phases 1, 2, and 3. While MH 21 was conceived as a resource development project of and for Japan, this national investment has become a global asset in the arena of methane hydrate R\&D. Through a host of international collaborations and by actively sharing technologies and information, the feasibility of responsible development of the worldwide methane hydrate resource for energy has improved.

Acknowledgments: Funding for this investigation was provided by the USA Office of Naval Research via Grant numbers N00014-13-1-0463 and N00014-14-1-054. The authors would also like to acknowledge the many useful discussions with current members of MH 21 and with Tsutomu Uchida of Hokkaido University. 
Author Contributions: Ai Oyama collected and translated the information; Stephen M. Masutani and Ai Oyama wrote the paper.

Conflicts of Interest: The authors declare no conflict of interest. The founding sponsors had no role in the design of the study; in the collection, analyses, or interpretation of information; in the writing of the manuscript, and in the decision to publish the results.

\section{References}

1. Collett, T.S.; Johnson, A.H.; Knapp, C.C.; Boswell, R. Natural gas hydrates: A review. AAPG Mem. 2009, 89, 146-219.

2. Masuda, Y.; Uchida, T.; Nagkubo, S.; Satoh, M. Methane hydrates. In Fossil Fuels: Current Status and Future Directions, World Scientific Series in Current Energy Issues 1; Crawley, G., Ed.; World Scientific Publishing: London, UK, 2016; Volume 1, pp. 289-327.

3. Narita, H. Recent states of R\&D on the methane hydrate exploitation and the progress. J. Jpn. Inst. Energy 2013, 92, 1107-1110. (In Japanese)

4. Texas A\&M University-Corpus Christi; Imhrd 2017. Available online: http://sci.tamucc.edu/events/ IMHRD/index.html (accessed on 22 July 2017).

5. Masutani, S.M.; Coffin, R.B. Final report of fiery ice from the seas. In Proceedings of the 1st Workshop of the International Conference Methane Hydrates, Honolulu, HI, USA, 7-9 March 2001.

6. Universidad Catolica de Valparaiso. Final report of 3rd International Methane Hydrate Workshop on R\&D. In Proceedings of the 3rd International Methane Hydrate Workshop on Research and Development, Viña del Mar, Chile, 18-21 November 2003.

7. Langhorne, N.; Tohidi, B.; Miles, P.; Rees, J.; Long, D.; Westbrook, G. The summary of 5th International Workshop on Methane Hydrate Research \& Development-Identifying the challenges. In Proceedings of the 5th International Workshop on Methane Hydrate R\&D, Edinburg, UK, 9-12 October 2006.

8. Kvamme, B.; Uchida, T.; Masutani, M.S.; Narita, H.; Coffin, R. The summary of 6th International Methane Hydrate Research and Development Workshop. In Proceedings of the 6th International Workshop on Methane Hydrate R\&D, Bergen, Norway, 13-15 May 2008.

9. Pecher, I.; Stagpoole, V.; Henrys, S. Report of workshop. In Proceedings of the 7th International Workshop on Methane Hydrate R\&D (Fiery Ice 2010), Wellington, New Zealand, 10-12 May 2010.

10. Fiery Ice International Steering Committee. Final Report of 8th International Workshop on Methane Hydrate Research \& Development Sapporo 2012 (full report). In Proceedings of the 8th International Workshop on Methane Hydrate R\&D, Sapporo, Japan, 28 May-1 June 2012.

11. Gupta, H.K.; Nayak, S.; Talukdar, S.B.N.; Srivastava, S.K.; Bhaskar Rao, Y.J.; Naqvi, S.W.A.; Atmanand, M.A.; Rajan, S.; Kumar, P.; Sain, K. Summary of the workshop. In Proceedings of the 9th International Methane Hydrate R\&D (Fiery Ice 2014), Hyderabad, India, 10-12 November 2014.

12. Ministry of Economy Trade and Industry. Fy2016 Annual Report on Energy; Ministry of Economy Trade and Industry: Tokyo, Japan, 2017. Available online: http:/ /www.enecho.meti.go.jp/about/whitepaper/ 2017pdf/whitepaper2017pdf_2_1.pdf (accessed on 18 July 2017). (In Japanese)

13. MH 21 Research Consortium. 2002-2017. Available online: http://www.mh21japan.gr.jp (accessed on 23 July 2017). (In Japanese)

14. New Energy and Industrial Technology Development Organization (NEDO). Commemorating the 40th Anniversary of the Sunshine Project; New Energy and Industrial Technology Development Organization (NEDO): Tokyo, Japan, 2014; pp. 1-9. Available online: http:/ /www.nedo.go.jp/content/100574164.pdf (accessed on 29 July 2017). (In Japanese)

15. Kato, K. Past progress and future prospects of photovoltaic technology R\&D. J. Inst. Electr. Eng. Jpn. 2004, 124, 786-789. (In Japanese)

16. Kinoshita, K. Improvement of energy efficiency for room airconditioners and electric refrigerators under the moonlight plans. Soai Univ. Dep. Bull. Pap. 1984, 31, 60-62. (In Japanese)

17. Yamazaki, K. Outline of new sunshine program. Jpn. Soc. Appl. Phys. 1994, 63, 762-769. (In Japanese)

18. Matsumoto, R. Overview of gas hydrate: Impact of the discovery of a large ice-like carbon reservoir under the seafloor. J. Geogr. 2009, 118, 7-42. (In Japanese) [CrossRef] 
19. Nagakubo, S. Geological properties of methane hydrate deposits and exploration of them. In State of the Art of Unconventional Natural Gas; Japan Institute of Energy, Ed.; Japan Industrial Publishing: Tokyo, Japan, 2014; pp. 160-166. (In Japanese)

20. Tanaka, S. Japan's Methane Hydrate R\&D Program and Its Progress. In Proceedings of the Japan's Methane Hydrate R\&D Program Results Reporting, Tokyo, Japan, 2004. (In Japanese)

21. Fujita, K.; Terasaki, T. Gas hydrate (i): Introduction to gas hydrate. J. Jpn. Inst. Energy 2001, 80, 765-777. (In Japanese)

22. Tanaka, S. Brief mention of the first phase of Japan's methane hydrate R\&D program. J. Jpn. Assoc. Petrol. Technol. 2009, 74, 265-269. (In Japanese)

23. Ichikawa, Y. Methane hydrate in the marine environment R\&D. J. Mar. Eng. Soc. Jpn. 1998, 33, 79-85. (In Japanese)

24. Satoh, M.; Maekawa, T.; Okuda, Y. Estimation of amount of methane and resources of natural gas hydrates in the world and around Japan. J. Geol. Soc. Jpn. 1996, 102, 959-971. (In Japanese) [CrossRef]

25. Nagakubo, S. Methane hydrate as a domestic energy resource; Japan's methane hydrate R\&D program. J. Geogr. 2009, 118, 758-775. (In Japanese)

26. Fujita, K. Methane hydrate R\&D in Japan. In State of the Art of Unconventional Natural Gas; Japan Institute of Energy, Ed.; Japan Industrial Publishing: Tokyo, Japan, 2014; pp. 24-29. (In Japanese)

27. Research Consortium for Methane Hydrate Resources in Japan (MH 21). New Natural Gas Resource Methane Hydrate-Japan's Methane Hydrate RED Program, Phase 2; Japan Oil, Gas and Metals National Corporation (JOGMEC): Tokyo, Japan, 2010. Available online: http://www.mh21japan.gr.jp/pdf/mh21panflet.pdf (accessed on 23 July 2017). (In Japanese)

28. Nagakubo, S. The exploration technology for methane hydrate. In State of the Art of Unconventional Natural Gas; Japan Institute of Energy, Ed.; Japan Industrial Publishing: Tokyo, Japan, 2014; pp. 187-201. (In Japanese)

29. Tanaka, S. The challenge for non-conventional gas resources of the 21st century-Japan's methane hydrate r \& d program. J. Jpn. Assoc. Petrol. Technol. 2003, 68, 149-155. (In Japanese)

30. The Research Consortium for Methane Hydrate Resources in Japan (MH 21 Research Consortium). Action Plan for the Phase 3; The Research Consortium for Methane Hydrate Resources in Japan: Tokyo, Japan, 2016. Available online: http:/ / www.meti.go.jp/committee/summary /0004108/pdf/031_07_00.pdf (accessed on 30 July 2017).

31. MH 21 Research Consortium. Japan's Methane Hydrate RED Program Phase 1-Comprehensive Report of Research Results; Japan Oil, Gas and Metals National Corporation (JOGMEC), Ed.; National Institute of Advanced Industrial Science and Technology (AIST); Engineering Advancement Association of Japan (ENAA): Tokyo, Japan, 2008; Available online: http://www.mh21japan.gr.jp/english/wp/wp-content/ uploads/ca434ff85adf34a4022f54b2503d86e92.pdf (accessed on 23 July 2017).

32. Hiroki, Y.; Watanabe, K.; Matsumoto, R. Lithology, biostratigraphy, and magnetostratigraphy of gas hydrate-bearing sediments in the eastern nankai trough. Resour. Geol. 2004, 54, 25-34. [CrossRef]

33. Jin, Y.; Nagao, J.; Hayashi, J.; Shimada, W.; Ebinuma, T.; Narita, H. Observation of xe hydrate growth at gas-ice interface by microfocus X-ray computed tomography. J. Phys. Chem. C 2008, 112, 17253-17256. [CrossRef]

34. Katsuki, D.; Ohmura, R.; Ebinuma, T.; Narita, H. Visual observation of dissociation of methane hydrate crystals in a glass micro model: Production and transfer of methane. J. Appl. Phys. 2008, 104. [CrossRef]

35. Fujii, T.; Nakamizu, M.; Tsuji, Y.; Namikawa, T.; Okui, T.; Kawasaki, M.; Ochiai, K.; Nishimura, M.; Takano, O. Methane-hydrate occurrence and saturation confirmed from core samples, eastern nankai trough, Japan. AAPG Mem. 2009, 89, 385-400.

36. Masuda, Y.; Yamamoto, K.; Tadaaki, S.; Ebinuma, T.; Nagakubo, S. Japan's methane hydrate R\&D program progresses to phase 2. Nat. Gas Oil 2009, 9, 1-6.

37. Japan Oil, Gas and Metals National Corporation (JOGMEC). Results on Methane Hydrate Resource Assessment in the Eastern Nankai Trough. 2007. Available online: http://www.jogmec.go.jp/news/ release/release0076.html (accessed on 24 August 2017). (In Japanese)

38. Ministry of Economy, Trade and Industry (METI). The Plan for the Development of Marine Energy and Mineral Resources; Ministry of Economy, Trade and Industry (METI): Tokyo, Japan, 2013. Available online: http:/ / www.meti.go.jp/committee/sougouenergy/shigen_nenryo/pdf/report01_01_00.pdf (accessed on 30 July 2017). (In Japanese) 
39. Japan Oil, Gas and Metals National Corporation (JOGMEC). Gas Production Amount in the First Methane Hydrate Offshore Production Test (Advanced Announcement Value). 2013. Available online: http://www. jogmec.go.jp/news/release/news_01_000004.html (accessed on 23 August 2017). (In Japanese)

40. Yamamoto, K. Overview and introduction: Pressure core-sampling and analyses in the 2012-2013 MH 21 offshore test of gas production from methane hydrates in the eastern nankai trough. Mar. Petrol. Geol. 2015, 66, 296-309. [CrossRef]

41. Fujii, T.; Suzuki, K.; Takayama, T.; Tamaki, M.; Komatsu, Y.; Konno, Y.; Yoneda, J.; Yamamoto, K.; Nagao, J. Geological setting and characterization of a methane hydrate reservoir distributed at the first offshore production test site on the daini-atsumi knoll in the eastern nankai trough, Japan. Mar. Petrol. Geol. 2015, 66, 310-322. [CrossRef]

42. Yamamoto, K.; Terao, Y.; Fujii, T.; Ikawa, T.; Seki, M.; Matsuzawa, M.; Kanno, T. Operational overview of the first offshore production test of methane hydrates in the Eastern Nankai trough. In Proceedings of the Offshore Technology Conference, Houston, TX, USA, 5-8 May 2014.

43. Japan Oil, Gas and Metals National Corporation (JOGMEC). JOGMEC and U.S. Netl Signed a Mou Concerning Japan-U.S. Collaboration on Methane Hydrate. 2014. Available online: http:/ /www.jogmec.go. jp/news/release/news_10_000156.html (accessed on 25 August 2017). (In Japanese)

44. Environment, Industrial Structure Council Subcommittee: Committee on Industrial Science and Technology Policy. Methane Hydrate RED Project, Interim Technical Evaluation Report (Tentative); Ministry of Economy, Trade and Industry: Tokyo, Japan, 2016; pp. 1-59. Available online: http:/ / www.meti.go.jp/committee/ sankoushin/sangyougijutsu/kenkyu_hyoka/hyoka_wg/pdf/029_05_02.pdf (accessed on 24 August 2017). (In Japanese)

45. Yamamoto, K. Marine Development System of Methane Hydrate: How is It Different from the Conventional Type? 2016. Available online: http://www.mh21japan.gr.jp/result_report/forum2016doc/ (accessed on 25 August 2017). (In Japanese)

46. Ministry of Economy, Trade and Industry (METI). Second Offshore Methane Hydrate Production Test Finishes. 2017. Available online: http:/ / www.meti.go.jp/press/2017/06/20170629004/20170629004.html (accessed on 23 August 2017). (In Japanese)

47. Ministry of Economy, Trade and Industry (METI). Basic Plan on Ocean Policy; Ministry of Economy, Trade and Industry (METI): Tokyo, Japan, 2013. Available online: http://www.kantei.go.jp/jp/singi/kaiyou/ kihonkeikaku/130426kihonkeikaku_e.pdf (accessed on 30 July 2017). (In Japanese)

48. Office, Cabinet Office Government Public Relations. Special Opinion Poll on Nuclear Power; Office, Cabinet Office Government Public Relations: Tokyo, Japan, 2009. Available online: http:/ / survey.gov-online.go.jp/ tokubetu/h21/h21-genshi.pdf (accessed on 28 August 2017). (In Japanese)

49. Iwai, N.; Shishido, K. The impact of the great east Japan earthquake and fukushima daiichi nuclear accident on peoples perception of disaster risks and attitudes toward nuclear energy policy. Jpn. Sociol. Rev. 2013, 64, 420-438. (In Japanese) [CrossRef]

50. Takahashi, K.; Masaki, M. How the great east Japan earthquake changed the Japanese: From a public opinion survey on disaster prevention, energy and basic sense of values. NHK Mon. Rep. Broadcast Res. 2012, 62, 34-55. (In Japanese)

51. Kono, K.; Masaki, M. Public opinion survey on "disaster prevention and energy" conducted three years after the great east Japan earthquake: Exploring the attitudes of the people across Japan and of the residents in afflicted areas. NHK Mon. Rep. Broadcast Res. 2014, 64, 2-29. (In Japanese)

52. Hosaka, S. Effort to ensure a stable resource and energy supply. Jpn. For. Trade Council Bull. 2013, 712, 12-15. (In Japanese)

53. Japan, Ministry of Foreign Affairs of Energy Security-To Ensure a Stable and Clean Energy Supply. 2013. Available online: http:/ / www.mofa.go.jp/mofaj/press/pr/wakaru/topics/vol103/index.html (accessed on 26 July 2017). (In Japanese)

54. The Contradiction of Japan: Against Nuclear Power Plant but also against Electricity Price Increase. The Nikkei. 11 March 2016. Available online: https:/ / www.nikkei.com/article/DGXMZO98208170Z00C16A3970M00/ (accessed on 28 August 2017). (In Japanese)

55. Tsuboi, S. Reconsidering the energy issues and future of Japan. Kansai Economy Now 2013, 2-7. (In Japanese) 
56. Fy2013 Annual Report on Energy; Ministry of Economy, Trade and Industry (METI): Tokyo, Japan, 2014. Available online: http:/ / www.enecho.meti.go.jp/about/whitepaper/2014pdf/whitepaper2014pdf_1_2.pdf (accessed on 25 July 2017). (In Japanese)

57. Curtis, J.B. Natural gas. In Fossil Fuels: Current Status and Future Directions: World Scientific Series in Current Energy Issues 1; Crawley, G.M., Ed.; World Scientific Publishing (UK): London, UK, 2016; Volume 1, pp. 203-227.

58. Yoshitake, J. Shale gas R\&D in north america (USA and Canada). In State of the Art of Unconventional Natural Gas; Japan Industrial Publishing: Tokyo, Japan, 2014; pp. 138-147. (In Japanese)

59. Yoshitake, J. The shale gas revolution and its impact to the world. In State of the Art of Unconventional Natural Gas; Japan Industrial Publishing: Tokyo, Japan, 2014; pp. 14-24. (In Japanese)

60. Japan Oil, Gas and Metals National Corporation (JOGMEC). Shale Gas Revolution-Status of Natural Gas around Japan and Energy Strategy. 2014. Available online: http://www.jogmec.go.jp/library/recommend_ library_01_000013.html (accessed on 26 July 2017). (In Japanese)

(C) 2017 by the authors. Licensee MDPI, Basel, Switzerland. This article is an open access article distributed under the terms and conditions of the Creative Commons Attribution (CC BY) license (http:/ / creativecommons.org/licenses/by/4.0/). 